\title{
Correlation The Number Of Erythrocytes And Glucose Level From Serum Which 2 Hours Delayed From Delayed
}

\author{
Eka yuniar $^{1}$, Bastian ${ }^{2}$, Endang.F ${ }^{4}$, Ian Kurniawan ${ }^{4}$ \\ ${ }^{1}$ Mahasiswa, Program Studi DIV TLM Universitas Katolik Musi Charitas Palembang \\ ${ }^{2}$ Lecture, Prodi TLM STIKes Muhammdiayah Palembang \\ ${ }^{3}$ Bagian Patologi Klinik RSK. Charitas Palembang \\ ${ }^{4}$ Lecture, Prodi TLM Unika Musi Charitas Palembang
}

\begin{tabular}{l} 
Article Info \\
\hline Article history: \\
Received Des $11^{\text {th }}, 2019$ \\
Revised Jan $31^{\text {th }}, 2020$ \\
Accepted Feb $02^{\text {nd }}, 2020$
\end{tabular}

Keyword:

The number of Erythrocyte, The level of Glucose, Pre-analytical.

\begin{abstract}
In the processing of specimens, serum specifically should be separated from blood cell the process of glucose glycolysis which caused decreasing levels of glucose. The very high number of erythrocyte can cause a glycolysis, so the decreasing of the levels of glucose will be happen. This study was pre-experiment using One Group Pretest Posttest. The sample was taken using purposive sampling technique and there were 30 subjects. The sample was EDTA bloods and serum which had been treated such as Separation of Glucose Serum which was 2 hours delayed and Separation of Glucose Serum which was checked directly. From this study we can found that the average of the glucose levels on serum separation which is 2 hours delayed was $91 \mathrm{mg} / \mathrm{dL}$ and the Separation of Glucose Serum which is checked directly was $97 \mathrm{mg} / \mathrm{dL}$. Based on paired $T$ test the result, the data showed that there were differences from average levels of glucose between serum which was checked directly and separation of Serum which was 2 hours delayed. The average from the number of erythrocyte was 5,0 million $/ \mu L$. Based on pearson correlation, there was no correlation between the number of erythrocyte and glucose level on serum separation which is 2 hours delayed.
\end{abstract}

Copyright $@$ Jurnal Analis Medika Bio Sains All rights reserved.

\begin{abstract}
ABSTRAK
Dalam pengolahan spesimen, serum khusus harus dipisahkan dari sel darah, proses glikolisis glukosa yang menyebabkan penurunan kadar glukosa. Jumlah eritrosit yang sangat tinggi dapat menyebabkan glikolisis, sehingga penurunan kadar glukosa akan terjadi. Tujuan penelitian ini mengetahui adakah korelasi antara jumlah eritrosit dengan kadar glukosa pada penundaan pemisahan serum selama 2 jam. Penelitian ini adalah pra-eksperimen dengan menggunakan One Group Pretest Posttest. Sampel diambil dengan menggunakan teknik purposive sampling dan ada 30 subjek. Sampel adalah darah EDTA dan serum yang telah diobati seperti Pemisahan Serum Glukosa yang tertunda 2 jam dan Pemisahan Serum Glukosa yang diperiksa langsung. Dari penelitian ini kami dapat menemukan bahwa rata-rata kadar glukosa pada pemisahan serum yang tertunda 2 jam adalah $91 \mathrm{mg} / \mathrm{dL}$ dan Pemisahan Glukosa Serum yang diperiksa langsung adalah 97mg / dL. Berdasarkan paired T test hasilnya, data menunjukkan bahwa ada perbedaan dari rata-rata kadar glukosa antara serum yang diperiksa langsung dan pemisahan serum yang tertunda 2 jam. Rata-rata dari jumlah eritrosit adalah 5,0 juta / $\mu \mathrm{L}$. Berdasarkan korelasi pearson, tidak ada korelasi antara jumlah eritrosit dan kadar glukosa pada pemisahan serum yang tertunda 2 jam.Berdasarkan penelitian ini dapat disimpulkan bahwa tidak terdapat korelasi jumlah eritrosit dengan kadar glukosa pada pemisahan serum yang ditunda 2 jam.
\end{abstract}

Kata Kunci : Jumlah Eritrosit, Kadar Glukosa, Pra-analitik 


\section{Pendahuluan}

Glukosa terbentuk dari karbohidrat yang disimpan sebagai glikogen di hati dan di otot rangka. Hormon yang dapat mempengaruhi kadar glukosa darah adalah insulin dan glukagon, yang berasal dari pankreas. Insulin diperlukan untuk permeabilitas membran sel terhadap glukosa dan untuk transportasi glukosa ke dalam sel. Proses metabolisme karbohidrat disebut glikolisis, karena hampir semua jenis gula baik yang berasal dari makanan atau reaksi katabolik dalam tubuh pada akhirnya di ubah menjadi glukosa. Glikolisis adalah prosesmpenguraian glukosa menjadi piruvat, kemudian menghasilkan dua molekul adenosin difosfat (ATP) dari molekul glukosa yang dimetabolisme (Champe et al, 2010).

Eritrosit adalah sel yang memiliki bentuk bikonkaf yang bersifat fleksibel sehingga dapat melewati lumen pembuluh darah yang sangat kecil untuk mengedarkan darah keseluruh tubuh. Eritrosit tidak memiliki organel intrasel seperti mitokondria, maka tidak ada produksi ATP oleh fosforilasi oksidatif. Eritrosit sangat bergantung pada glukosa sebagai sumber energi utamanya, di dalam membran eritrosit mengandung pengangkut glukosa. Tiap molekul glukosa glukosa yang digunakan, dihasilkan dua molekul ATP dan dua ikatan fosfat yang berenergi tinggi. Adenosin trifosfat yang menyediakan energi untuk eritrosit mempertahankan volume, bentuk dan kelenturan sel (Murray, 2003). Eritrosit memiliki pengangkutan glukosa didalam membrannya. Membran ini berfungsi membatasi perpindahan zat-zat yang terlibat dalam reaksi yang terjadi dalam sel maupun masuknya zat-zat dari luar sel. Membran memiliki sifat dapat memilih atau melakukan seleksi zat-zat dari dalam sel yang boleh keluar atau zat-zat dari luar yang boleh masuk ke dalam sel (Sadikin, 2001).

Pada pemeriksaan laboratorium terbagi menjadi tiga tahap yaitu : pra analitik analitik dan pasca analitik. Pada tahap pra analitik adalah tahap penyebab kesalahan terbesar yaitu 68,2\%, dibandingankan dengan tahap analitik 18,5\% dan pasca analitik 13,3\% (Medical Laboratory, 2008). Pemisahan sel darah dan serum merupakan tahap pra analitik pengolahan sampel untuk pemeriksaan glukosa. Serum secara fisik harus dipisahkan dengan sel darah untuk menghindari proses glikolisis glukosa yang menyebabkan kadar glukosa menurun dari nilai yag sebenarnya. Jumlah eritrosit yang sangat tinggi dapat menyebabkan glikolisis berlebih dalam sampel, sehingga terjadi penurunan glukosa yang sangat bermakna (Sacher \& McPherson, 2004).

Menurut Tietz dalam Datta et al, (2014) menyatakan waktu minimal pemisahan serum dengan sel yang masih dapat diterima yaitu 20-30 menit (waktu pembekuan darah). Menurut National Commite For Clinical Laboratory (NCCLS) Infobase ; Young dan Bermes dalam Nwosu \& Nwani (2008) menyatakan waktu maksimal pemisahan serum dengan sel 2 jam dari waktu pengambilan spesimen.

Penelitian yang dilakukan Christiane (2012) menunjukkan bahwa terdapat perbedaan yang signifikan antara glukosa yang langsung diperiksa dengan glukosa yang ditunda pemisahan. Penelitian ini sejalan dengan Putra A.R, Hidayat E.M dan Tahadeus M.S (2012) yang menunjukkan bahwa terdapat perbedaan yang signifikan antara glukosa yang langsung diperiksa dengan glukosa yang ditunda pemisahan 1 jam, 2 jam, 3 jam dan 4 jam. Kedua penelitian tersebut belum melihat adanya korelasi penundaan pemisahan serum dengan jumlah eritrosit, sehingga peneliti terarik melihat sejauh mana jumlah eritrosit mempengaruhi kadar glukosa pada penundaan pemisahan serum, dengan tujuan tujuan penelitiian ini yaitu mengetahui adakah korelasi antara jumlah eritrosit dengan kadar glukosa pada penundaan pemisahan serum selama 2 jam. 


\section{Metode Penelitian}

Alat yang digunakan dalam penelitian ini adalah ATK, test request, alat hitung sel darah otomatis Sysmex KX-21, alat pemeriksaan kimia klinik otomatis BioSystem A15, sentrifus, tabung antikoagulan $\mathrm{K}_{2}$ EDTA, tabung aktivator pembekuan, spuit $5 \mathrm{cc}$, tourniquet, stopwacth (jam), mikropipet 250 $\mu 1$, blue tip, sampel cup (pediatrick sampel), rak tabung dan alkohol swab. Bahan pemeriksaan dalam penelitian ini adalah darah lengkap (whole blood), serum dengan pemisahan segera dan serum dengan penundaan pemisahan selama 2 jam.mReagen Kit A15 Glukosa dari BioSystem, Spanyol no.lot 11619 exp date 04.2018. Reagen Kit Sysmex KX-21 dari Sysmex Corporation, Japan. Cellpack no.lot AM6037, exp date 04.04.2016.

Penelitian ini merupakan pre-eksperimen menggunakan One Group Pretest Posttest. Pengambilan sampel menggunakan teknik purposive sampling dan diperoleh sebanyak 30 sampel . Bahan pemeriksaan berupa darah EDTA dan serum dengan pengolahan sampel yaitu, pemisahan serum segera dan pemisahan serum yang ditunda 2 jam. Pengambilan darah vena menggunakan tabung vakum. Untuk pemeriksaan eritrosit, darah dengan antikoagulan EDTA tidak ada pengolahan khusus cukup dihomogenkan kembali darah dengan cara membolak-balik tabung sebanyak 8 kali, sebelum dilakukan pemeriksaan dengan alat otomatis sysmex KX-21. Untuk pemeriksaan kadar glukosa pemisahan serum segera, darah dalam tabung aktivaktor pembekuan pertama dilakukan pengolahan sehingga menjadi serum, dengan cara: Biarkan darah membeku terlebih dahulu selama 20-30 menit, kemudian disentrifus 3500 rpm selama 5 menit. Lakukan segera pemisahan serum dengan sel menggunakan mikropipet. Masukan serum kedalam pediatrick sampel. Lakukan pemeriksaan menggunakan alat otomatis A15. Untuk pemeriksaan kadar glukosa pemisahan serum ditunda, darah dalam tabung aktivaktor pembekuan kedua dilakukan pengolahan sehingga menjadi serum, dengan cara : Biarkan serum dengan sel darah kontak selama 2 jam, kemudian disentrifus 3500 rpm selama 5 menit. Lakukan pemisahan serum dengan sel menggunakan mikropipet. Masukan serum kedalam pediatrick sampel. Lakukan pemeriksaan menggunakan alat otomatisData yang diperoleh kemudian diolah secara statistik dengan menggunakan uji T berpasangan, dilanjutkan dengan uji korelasi pearson.

\section{Hasil Penelitian dan Pembahasan}

\section{Data Hasil Penelitian}

Tabel 1 Data Hasil Pemeriksaan

\begin{tabular}{lcccc}
\hline & \multirow{2}{*}{$\begin{array}{c}\text { Jumlah } \\
\text { Eritrosit } \\
(\text { Juta/ } \mu \mathrm{L})\end{array}$} & $\begin{array}{c}\text { Segera } \\
(\mathrm{mg} / \mathrm{dL})\end{array}$ & $\begin{array}{c}\text { Serum } \\
\text { Ditunda } \\
(\mathrm{mg} / \mathrm{dL})\end{array}$ & $\begin{array}{c}\text { Selisih } \\
(\mathrm{mg} / \mathrm{dL})\end{array}$ \\
\cline { 3 - 5 } & & 97 & 91 & 6 \\
\hline Mean & 5,0 & 124 & 124 & 16 \\
Max & 6,2 & 72 & 65 & 0 \\
Min & 4,3 & 13 & 13 & 4 \\
\hline
\end{tabular}


Jumlah eritrosit memiliki nilai rata-rata sebesar 5,0 $\pm 0,52$ juta/ $\mu \mathrm{L}$ dengan nilai maksimum sebesar $6,2 \mu \mathrm{L}$ dan nilai minimum yaitu 4,3 $\mu \mathrm{L}$. Kadar glukosa pada pemisahan serum segera memiliki nilai rata-rata sebesar 97士13 mg/dL dengan nilai maksimum yaitu $124 \mathrm{mg} / \mathrm{dL}$ dan nilai minimum yaitu $72 \mathrm{mg} / \mathrm{dL}$. Kadar glukosa pada pemisahan serum yang ditunda selama 2 jam memiliki nilai rata-rata sebesar $91 \pm 13 \mathrm{mg} / \mathrm{dL}$ dengan nilai maksimum sebesar $124 \mathrm{mg} / \mathrm{dL}$ dan nilai minimum yaitu $65 \mathrm{mg} / \mathrm{dL}$. Selisih kadar glukosa pada pemisahan serum segera dan yang ditunda 2 jam memiliki nilai rata-rata sebesar $6 \pm 4 \mathrm{mg} / \mathrm{dL}$ dengan nilai maksimum sebesar $16 \mathrm{mg} / \mathrm{dL}$ dan nilai minimum yaitu $0 \mathrm{mg} / \mathrm{dL}$. Kadar glukosa pada pemisahan serum yang ditunda 2 jam memiliki nilai rata-rata lebih kecil dibandingkan dengan kadar glukosa pada pemisahan serum segera.

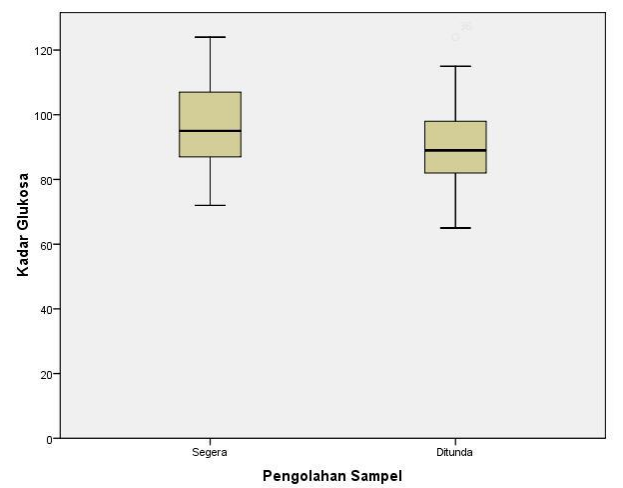

Gambar 1 Rata-Rata Kadar Glukosa Darah pada Pemisahan Serum Segera dan Pemisahan Serum yang ditunda 2 Jam

Berdasarkan gambar 1 diatas dapat diketahui terdapat penurunan sacara rata-rata kadar glukosa pada pemisahan pemisahan serum $(97 \pm 13 \mathrm{mg} / \mathrm{dL})$ dan yang ditunda 2 jam $(91 \pm 13 \mathrm{mg} / \mathrm{dL})$ lebih rendah dari kadar glukosa pada pemisahan serum segera.

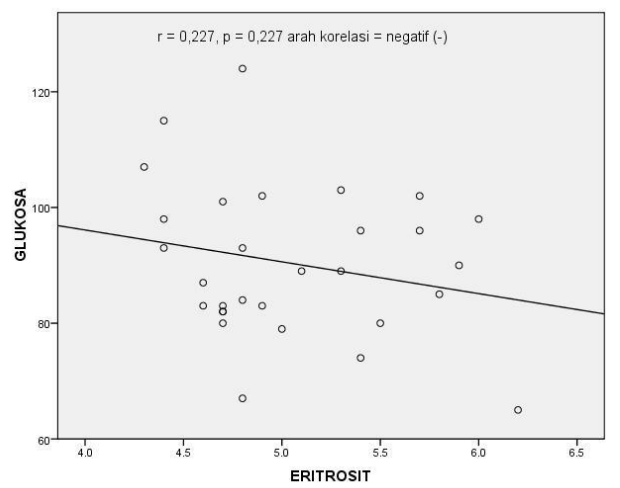

Gambar 2 Korelasi jumlah eritrosit dengan kadar glukosa pada pemisahan serum yang ditunda 2 jam

Berdasarkan gambar 4.2 diatas dapat diketahui tidak terdapat korelasi antara jumlah eritrosit dengan kadar glukosa pada pemisahan serum yang ditunda 2 jam dengan nilai $p=0,0227>\alpha=0,05$. 
Jurnal Analis Medika Bio Sains

Vol.7, No.1, Maret 2020, pp. 19 - 25

ISSN: 2656-2456 (Online)

ISSN: 2356-4075 (Print)

\section{Pembahasan}

Hasil penelitian pada tabel 1 didapatkan rata-rata kadar glukosa pada pemisahan serum segera sebesar $97 \pm 13 \mathrm{mg} / \mathrm{dL}$ dan pemisahan serum yang ditunda selama 2 jam sebesar $91 \pm 13 \mathrm{mg} / \mathrm{dL}$. Rata-rata kadar glukosa pada pemisahan serum yang ditunda 2 jam lebih kecil dibandingkan dengan kadar glukosa pada pemisahan serum segera. Secara rata-rata terjadi penurunan kadar glukosa darah pada pemisahan serum yang ditunda selama 2 jam, dengan nilai kadar glukosa pada pemisahan serum yang segara yang dianggap base line dalam penelitian ini. Hasil rata-rata kadar glukosa darah pada pemisahan serum segera sebesar $97 \pm 13$

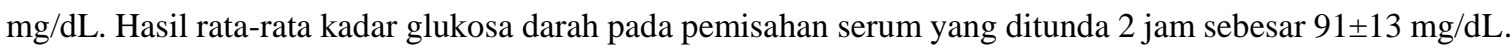
Secara uji statistik uji paired sampel T-test menunjukkan adanya perbedaan yang signifikan $(\mathrm{p}=0,001<$ $0,005)$.

Penelitian terdahulu yang dilakukan oleh Putra, Hidayat dan Thaudeus (2012) terhadap 88 sampel yang memenuhi kriteria inklusi dengan perlakuan penundaan pemisahan serum dengan sel darah selama 1, 2, 3 dan 4 jam menggunakan metode heksokinase. Hasil penelitian menunjukkan bahwa terdapat perbedaan kadar glukosa dari darah yang langsung diperiksa $(95 \mathrm{mg} / \mathrm{dL})$ dengan kadar glukosa darah yang mengalami penundaan pemisahan serum selama 1 jam (90 mg/dL), 2 jam $(86 \mathrm{mg} / \mathrm{dL}), 3 \mathrm{jam}(82 \mathrm{mh} / \mathrm{dL})$ dan 4 jam $(78$ $\mathrm{mh} / \mathrm{dL}$ ). Penelitian yang dilakukan Christiane et al, (2012) terdapat 10 sampel yang memenuhi kriteria inklusi dengan perlakuan penundaan pemisahan serum dengan sel darah selama 2, 4, 6 dan 24 jam menggunakan metode heksokinase. Hasil penelitian menunjukkan bahwa terdapat perbedaan kadar glukosa dari darah yang langsung diperiksa 4,73 mmol/L (85,14 mg/dL) dengan kadar glukosa darah yang mengalami penundaan pemisahan serum pada suhu $25^{\circ} \mathrm{c}$ selama 2 jam turun 9,5\%, 4 jam turun $17 \%, 6$ jam turun $19,7 \%$, dan 24 jam turun 62,8 \% .Hasil perbedaan kadar glukosa dengan pemisahan serum segera dan yang ditunda 2 jam pada penelitian ini sejalan dengan penelitian yang dilakukan oleh Christiane et al, (2012), Putra, Hidayat dan Thaudeus (2012) dan teori yang ada bahwa jika serum dengan sel darah tidak segera dipisah maka akan terjadi glikolisis yang menyebabkan kadar glukosa turun.

Menurut Brunsh, 2009, jika serum dengan sel darah tidak segera dipisah maka akan terjadi glikolisis yang menyebabkan kadar glukosa turun 5-7\% perjam. Penelitian yang dilakukan oleh Christiane et al, (2012), kadar glukosa pemisahan serum yang ditunda 2 jam mengalami penurunan $9,4 \%$ dan penurunan sebesar 9,5 $\%$ untuk penelitian yang dilakukan oleh Putra, Hidayat dan Thaudeus (2012). Pada penelitian ini pemisahan serum yang ditunda 2 jam mengalami penurunan $6,1 \%$, perbedaan penurunan kadar glukosa ini disebabkan oleh perbedaan waktu 0 hingga 2 jam pemisahan serum. Penelitian yang dilakukan oleh Christiane et al, (2012) dan Putra, Hidayat dan Thaudeus (2012) waktu pemisahan serum yang ditunda 2 jam mulai terhitung dari waktu pembekuan darah yaitu 20-30 menit. Pada penelitian ini waktu pemisahan serum yang ditunda 2 jam mulai terhitung dari waktu pengambilan spesimen. Menurut National Commite For Clinical Laboratory (NCCLS) Infobase ; Young dan Bermes dalam Nwosu \& Nwani (2008) menyatakan waktu maksimal pemisahan serum dengan sel 2 jam dari waktu pengambilan spesimen. 
Pada tahap pra analitik untuk pemeriksaan glukosa, serum harus segera dipisahkan dengan sel darah setelah darah membeku 20-30 menit dari pengambilan spesimen. Menurut National Commite For Clinical Laboratory (NCCLS) Infobase ; Young dan Bermes dalam Nwosu \& Nwani (2008) menyatakan waktu maksimal pemisahan serum dengan sel 2 jam dari waktu pengambilan spesimen. Pengolahan bahan pemeriksaan, serum secara fisik harus dipisahkan dengan sel darah untuk menghindari proses glikolisis glukosa yang menyebabkan kadar glukosa menurun dari nilai yang sebenarnya. Jumlah eritrosit yang sangat tinggi dapat menyebabkan glikolisis berlebihan dalam sampel, sehingga terjadi penurunan glukosa yang sangat bermakna (Sacher,dkk, 2004).

Pada penelitian ini jumlah subjek penelitian adalah 30 orang, dengan jenis kelamin laki-laki sebanyak 8 orang dan 22 orang perempuan. Usia rata-rata subjek penelitian adalah 20 tahun, dengan nilai minimum 18 tahun dan nilai maksimum 22 tahun. Nilai rujukan jumlah eritrosit dibedakan berdasarkan jenis kelamin, lakilaki dewasa 4,5-6,5 juta/ $\mu 1$ dan perempuan dewasa 3,8 - 4,8 juta/ $\mu 1$. Menurut Champe, 2010, glikolisis adalah proses penguraian glukosa menjadi piruvat, kemudian menghasilkan dua molekul adenosin trifosfat (ATP) dari molekul glukosa yang dimetabolisme. Sel eritrosit membutuhkan glukosa sebagai sumber energinya, dua molekul adenosin trifosfat (ATP) dari molekul glukosa menyediakan energi untuk sel eritrosit mempertahankan volume, bentuk bikonkaf dan kelenterunnya (Murray, 2003). Glukosa tidak dapat berdifusi langsung kedalam sel, tetapi dapat masuk melalui sistem transport yang disebut dengan glucose transporter (GLUT). Sistem transport GLUT-1 yang merupakan transporter untuk sel eritrosit (Champe, 2010). Hal ini yang menyebabkan kadar glukosa turun dalam serum, karena molekul glukosa diubah menjadi ATP untuk eritrosit mempertahankan bentuk dan kelenteranya dengan bantuan glucose transporter-1 (GLUT-1).

Pada penelitian ini tidak terdapat korelasi antara jumlah eritrosit dengan kadar glukosa pada pemisahan serum yang ditunda 2 jam. Hasil penelitian berlawanan dengan hipotesis yaitu tidak terdapat korelasi antara jumlah eritrosit dengan kadar glukosa pada pemisahan serum yang ditunda 2 jam. Secara uji statistik pearson kekuatan korelasi (r) 0,227, arah korelasi negatif (-) dan p = 0,227. Menurut Dahlan, 2009, nilai kekuatan korelasi (r) 0,20 - 0,399 interpretasi kekutan korelasi (r) lemah dan arah korelasi negatif (-) berlawanan arah yaitu, semakin besar nilai suatu variabel, semakin kecil nilai variabel lainnya. Nilai $p=0,227>0,05$ dapat disimpulkan bahwa tidak terdapat korelasi antara dua variabel yang diuji (Dahlan, 2009). Pada teori sebelumnya menyebutkan bahwa jumlah eritrosit yang sangat tinggi dapat menyebabkan glikolisi berlebih yang terjadi penurunan kadar glukosa yang bermakna. Pada penelitian ini didapatkan kadar rata-rata jumlah eritrosit 5,0 $\pm 0,52 \mathrm{juta} / \mu \mathrm{L}$, dengan nilai maksimal $6,2 \mathrm{juta} / \mu \mathrm{L}$ dan nilai minimal 4,3 juta/ $\mu \mathrm{L}$ yang masih masuk dalam rentang nilai jumlah eritrosit normal untuk pria dewasa dan wanita dewasa. Jumlah eritrosit pada penelitian ini tidak melebihi batas jumlah eritrosit normal, sehinnga tidak memiliki korelasi antara jumlah eritrosit dengan kadar glukosa pada pemisahan serum yang ditunda 2 jam.

Pada penelitian ini tidak terdapat korelasi antara jumlah eritrosit dengan kadar glukosa pada pemisahan serum yang ditunda 2 jam. Hasil penelitian berlawanan dengan teori dan hipotesis. Pada proses glikolisis yang terjadi pada saat sel darah dan serum masih kontak, tidak hanya eritrosit saja yang menggunakan energi glukosa sebagai sumber energi, leukosit dan trombosit menggunakan glukosa juga sebagai sumber energi. Penurunan kadar glukosa bukan hanya disebabkan oleh jumlah sel eritrosit, leukosit dan trombosit 
Jurnal Analis Medika Bio Sains

Vol.7, No.1, Maret 2020, pp. 19 - 25

ISSN: 2656-2456 (Online)

ISSN: 2356-4075 (Print)

juga ikut menyebabkan kadar glukosa menurun pada proses glikolisis pada saat serum dan sel darah dibiarkan kontak selama 2 jam.

\section{Kesimpulan}

Berdasarkan hasil penelitian yang dapat dsimpulkan bahwa tidak terdapat korelasi jumlah eritrosit dengan kadar glukosa pada pemisahan serum yang ditunda 2 jam.

\section{Daftar Pustaka}

Bruns DE \& Knowler W (2009). Stabilizatin of Glucose in Blood Samples : Why It Matters. Clinical Chemistry : 55 (5) 850-852. Diaskes November 2015.

Champe PC, Harvey RA \& Ferrier DR (2010). Biokimia Ulasan Bergambar. Jakarta: EGC, pp : 116-118.

Care : The Scandinavian Journal of Clinical \& Laboratory Investigation. Vol 69 (3) Hal : 350-358. Diaskes Juni 2016.

Datta RR, Baruah A, Pathak MS, Barman M, Borah MB (2014). Effect of Temperature and Serum-Clot Contact Time on the Clinical Chemistry. ISSN : Indian journal of Basic and Applied Medical Research, 4 (1) 356 - 362. Diaskes November 2015.

Dahlan S (2009). Statistik Untuk Kedokteran dan Kesehatan. Deskriptif, Bivariat, dan Multivariat Dilengkapi Aplikasi dengan Menggunakan SPSS. Edisike 5. Jakarta : Salemba Medika, pp : 4 ; 22.

Heijnen HFG, Oorschot V, Sixma JJ, Slot JW \& James DE (1997). Trombin Stimulates Glucose Transport in Human Platelets Via the Translocation of the from $\alpha$-Granules to the Cell. The Journal of Cell Biology, Vol :138 (323-330). Diaskes Juni 2016.

Korgun DK, Sarikaoglu SB, Altuntas H, Demir R \& Korgun ET (2009). Type-2 Diabetes Down

Murray RK, Granner Daryl K, Mayes Peter A \& Rodwell Victor W (2003). Biokimia Harper. Edisike 25. Jakarta: EGC, pp : 729-731.

Nwosu, O. K \& Nwani, C. D (2008). Stability of Serum/Plasma Glucose for the Diagnosis of Diabetes Mellitus. ISSN : Bio-Research, 6 (2) 380 - 383. Diaskes November 2015

Putra A.R, Hidayat E.M dan Tahadeus M.S (2012). Dampak pemisahan dari sel darah terhadap hasil pemeriksaan kadar glukosa darah menggunakan metode heksokonase. BINAWIDYA.Vol 23 No 5.264270

Sacher RA \& McPherson RA (2004). Tinjauan Klinis Hasil Pemeriksaan Laboratorium. Jakarta: EGC, p : 288. Sadikin H.M (2001). Biokimia Darah.Jakarta: Widya Medika, pp : $12-15$.

Oddoze Christiane, Lombard Elise \& Portugal Henri (2012). Stability study of 81 analytes in human whole blood, in serum and in plasma. ELSEVIER : Clinical Biochemistry (45) $464-469$. Diaskes November 2015. 